\title{
RELATIONSHIP BETWEEN VULVA HYGIENE AND VULVOVAGINALIS CANDIDIASIS OF REPRODUCTION AGE WOMAN IN PUBLIC HEALTH CENTER CIPAYUNG
}

\section{Hubungan Kebersihan Vulva dengan Genesis Kandidiasis Vulvavaginalis Pada Wanita Usia Subur di Puskesmas Cipayung}

\author{
Marni Br Karo ${ }^{1,{ }^{*}, a}$, Nurfauziah Cahyanti ${ }^{1}$, Farida Simanjuntak ${ }^{1}$, R. Haryo Bimo Setiarto ${ }^{2, *, a}$ \\ ${ }^{1}$ Midwifery Program of Medistra Health Higher School, Jakarta, Indonesia \\ ${ }^{2}$ Microbiology Division, Research Center for Biology LIPI, Bogor, Indonesia \\ *Email: marnikaro.stikesmi@gmail.com, haryobimo88@gmail.com
}

Naskah masuk 13 Febuari 2019; review 18 April 2019; disetujui terbit 31 Desember 2019

\begin{abstract}
Abstrak
Latar belakang: Kandidiasis vulvovaginalis adalah infeksi mukosa pada vagina maupun vulva yang disebabkan oleh jamur Candida. Infeksi terjadi secara akut, subakut, dan kronis, baik endogen maupun eksogen yang menimbulkan keluhan pada vagina. Umumnya infeksi pertama di vagina disebut vulvitis.

Tujuan: Penelitian ini bertujuan menganalisis hubungan kebersihan vulva dengan kejadian kandidiasis vulvovaginalis pada usia subur di Puskesmas Kecamatan Cipayung.

Metode: Penelitian dilakukan dengan menggunakan pendekatan cross sectional. Penelitian dilakukan pada bulan Februari sampai Juli 2018 di Unit Infeksi Menular Seksual Puskesmas Kecamatan Cipayung. Populasinya adalah sejumlah orang yang datang ke Puskesmas Kecamatan Cipayung. Sampel adalah sebanyak 33 orang, metode pengambilan sampel adalah secara accidental sampling kemudian data dikumpulkan dengan menyebarkan kuesioner dan pemeriksaan laboratorium. Analisis statistik yang digunakan adalah Chi-Square.

Hasil: Hasil penelitian menunjukkan bahwa kebersihan vulva tidak baik $(75,8 \%)$ dan berpengaruh positif terhadap kandidiasis vulvovaginalis di Puskesmas Cipayung (87,9\%). Hasil uji statistik diperoleh nilai $p=$ 0,036 ( $p<0,05$ ), atau ada hubungan kebersihan vulva dengan kejadian kandidiasis vulvovaginalis pada wanita usia subur di Puskesmas Cipayung.

Kesimpulan: Kebersihan vulva ada hubungannya dengan kejadian kandidiasis vulvovaginalis di Puskesmas Kecamatan Cipayung. Hal ini disebabkan oleh kurangnya kebersihan vagina pada wanita usia subur yang menyebabkan meningkatnya kejadian kandidiasis.
\end{abstract}

Kata kunci: Kebersihan vulva, kandidiasis vulvovaginalis, wanita usia subur, puskesmas cipayung

\begin{abstract}
Background: Vulvovaginalis candidiasis is infection in the mucosal of vagina or vulva caused by Candida fungus. Infection can occur acutely, subacute, and chronic, both endogenously and exogenously which often cause symptoms in the vagina. Generally, first infection in the vagina called vulvitis.

Objective: This study aims to determine the association of the vulva higiene with vulvovaginal candidiasis on fertile age in Cipayung sub-district Public Health Center (PHC).

Method: The study used cross sectional design approach. The study was conducted from February to July 2018 in sexually transmitted infection unit. Total sample was 33 patients at Cipayung sub-district PHC. The sampling method is purposive sampling and data were collected by questionnaire and laboratory results. Statistical analysis used is Chi-Square.

Results: The results showed that the vulva hygiene was poor $(75.8 \%)$ and there was positive association with vulvovaginal candidiasis in Cipayung PHC (87.9\%). The result of statistical tests obtained p-value $=0.036(\mathrm{p}$ $<0.05$ ), or there is a relationship of vulva hygiene with vulvovaginal candidiasis in women of childbearing age at Cipayung PHC.

Conclusion: There is a relationship between vulva hygiene and vulvovaginal candidiasis at Cipayung subdistrict PHC due to lack of vaginal hygiene on woman of childbearing age, which increased the incidence of candidiasis.
\end{abstract}

Keywords: Vulva hygiene, vulvovaginal candidiasis, woman age reproductive, public health center cipayung 


\section{BACKGROUND}

Vulvovaginal Candidiasis (VVC) is a vaginal or vulvar infection by Candida sp. with clinical manifestations that can occur acute or chronic. ${ }^{1}$ It is estimated that $75 \%$ of women will experience one vulvovaginal candidiasis episode and 40 to $50 \%$ will have two or more, vulvar symptoms such as itching, burning, irritation, odor and vaginal discharge. ${ }^{2}$ It can also make walking, urinating or having sex very painful ${ }^{1}$. Vulvovaginal candidiasis (VVC) is an infection of the female genital system that occurs due to Candida species. ${ }^{3}$ The most common causes of VVC were Candida albicans (80-90\%), followed by Candida glabrata (29.79\%), Candida tropicalis (3.19\%), Candida krusei (2.13\%), and Candida parapsilosis (1.06\%). ${ }^{4,5}$ Candidiasis itself is the most frequent cause of vaginal discharge as the prevalence is $40 \%$, with the characteristic of the discharge is usually thick, milky white, bad smell, and accompanied by intense itching in the genitals. ${ }^{6}$ Candida species produces two main enzymes that play a role in virulence, namely proteinase and phospholipase. The most common cause of Vulvovaginal candidiasis is Candida albicans, whose spread can be affected by the production of extracellular hydrolytic enzymes, namely: secreted aspartyl proteinase (SAP), B phospholipase enzyme, and lipase. ${ }^{7}$

Indonesia has tropical seasons that create body moister and sweatier. As a result, bacteria easily develop and cause unpleasant odors, especially in the closed body folds such as the armpits and folds of genetalia in women. To keep the body in a clean condition, someone must pay attention to personal hygiene. ${ }^{8}$ Cleanliness is very important and must be considered because cleanliness will affect a person's health and behaviour. Personal hygiene is an action to maintain one's cleanliness and health, to maintain physical and psychological well-being. ${ }^{9,10}$
Vulvovaginal candidiasis is the second most common cause of diseases affecting women in Europe and the United States. In India in 2013, VVC $(53,3 \%)$ against groups of women of reproductive age between 21-30 years with Candida albicans is the most common cause $(86 \%){ }^{8}$ According to WHO, the highest incidence rates of vulvovaginal candidiasis were recorded in South and Southeast Asia, followed by Africa, Latin America and the Caribbean. Research in the Department of Microbiology, Lead City University, Nigeria in 2012 conducted on 200 visitors of the Association for Reproductive Family and Health (AFRH) stated that Candida albicans infection was the highest infection with a percentage of $27 \% .^{6}$

Ministry of Health found that the ethiology of most of the 168 patients who come for treatment to the Public Health Center (PHC) Cempaka Putih Barat I, Jakarta is candidiasis by $52.8 \%$. The study also reported that out of 18 pregnant women and 25 non-pregnant women who were not having family planning and experienced vaginal discharge, most of them were infected with candidiasis, namely $66.7 \%$ and $48 \%$ resepectively. ${ }^{11}$ Vulvovaginal candidiasis is the second-order disease of all vaginal infections. ${ }^{2,11}$

Based on morbidity data in the Division of Sexually Transmitted Infections (STI) of Outpatient (UR) Skin and Sex Health in the 2007-2009 period, 242 new VVC patients were found, which were $19.7 \%$ of the total visits of patients with STI divisions and $1.05 \%$ of the number of new patient visits from URJ Dr. Soetomo Surabaya. ${ }^{10}$ This study aims to determine the association of the vulva hygiene with vulvovaginal candidiasis events on fertile age at Cipayung PHC in 2018.

\footnotetext{
* Corresponding author

(Email: marnikaro.stikesmi@gmail.com, haryobimo88@gmail.com)
}

(C) National Institute of Health Research and Development ISSN: 2354-8762 (electronic); ISSN: 2087-703X (print) 


\section{METHOD}

The study was conducted from February to July 2018 in sexually transmitted infection unit, by conducting interview to 125 patients, which were 46 positive VVC. After conducting the interview patients in sexually transmitted infection unit generally do not maintain the cleanliness of their vaginas or lack of vulva hygiene. On May 23, 2018 the author conducted a Preliminary Study at Cipayung PHC East Jakarta. Two of 5 patients who visited in sexually transmitted infection unit with symptom of vaginal discharge, and diagnosed with positive vulvovaginal candidasis after laboratory tests did not maintain the cleanliness of their vaginas.

This research used quantitative approach. Study samples were women of childbearing age (1549 years) who experienced vaginal discharge and laboratory examinations, using purposive accidental sampling of 33 people.

This study used primary and secondary data. Primary data were directly obtained from the questionnaire filled by the respondents, while secondary data were obtained from the register book of the laboratory examination in Cipayung PHC. Data analysis was performed using SPSS 20 , univariate analysis was used to describe the frequency distribution of vulva hygiene and the incidence of VVC among women of childbearing age, meanwhile bivariate analysis on the relationship of vulva hygiene variables with the incidence of VVC used Chi-Square test.

\section{HASIL}

Table 1 showed that out of 33 women of childbearing age who experienced vaginal discharge and had laboratory tests at Cipayung PHC in 2018, the results on vulva hygiene was poor $(75.8 \%)$ of 33 women of childbearing age who experienced vaginal discharge and had laboratory examinations at Cipayung PHC in 2018 the highest results were positive VVC, accounting for 29 respondents $(87.9 \%)$.

Based on Table 2, out of 25 respondents who had poor vulva, positive vulvovaginal candidiasis was in 24 respondents $(96.0 \%)$ whereas one respondent was negative $(4.0 \%)$. Of the 8 respondents with vulva hygiene, five respondents were positive for vulvovaginal candidiasis $(62.5 \%)$ and three respondents were negative $(37.5 \%)$ with $\mathrm{p}$ value $=0.036(\mathrm{p}$ $<0.005)$.

Table 1. Distribution of Vulva Hygiene Frequency and Frequency of Vulvovaginal Candidiasis in Fertile Age Women at Cipayung Public Health Center in 2018

\begin{tabular}{cccccc}
\hline Vulva Hygiene & Frequency & $\%$ & Laboratory results & Frequency & $\%$ \\
\hline Good & 8 & 24.2 & Negative & 4 & 12.1 \\
Poor & 25 & 75.8 & Positive & 29 & 87.9 \\
Total & 33 & 100.0 & Total & 33 & 100.0 \\
\hline
\end{tabular}

Source: Data Processing Results, July 2018

Table 2. Relationship of Vulva Hygiene with Vulvovaginal Candidiasis in Fertile Age Women in Cipayung Public Health Center in 2018

\begin{tabular}{|c|c|c|c|c|c|c|c|}
\hline \multirow[b]{3}{*}{ Vulva Hygiene } & \multicolumn{4}{|c|}{ Vulvovaginal Candidiasis } & \multirow[b]{3}{*}{ Total } & \multirow[b]{3}{*}{$\%$} & \multirow[b]{3}{*}{$\mathrm{P}_{\text {Value }}$} \\
\hline & \multicolumn{2}{|c|}{ Positive (+) } & \multicolumn{2}{|c|}{ Negative (-) } & & & \\
\hline & $\mathrm{F}$ & $\%$ & $\mathrm{~F}$ & $\%$ & & & \\
\hline Good & 5 & 62.5 & 3 & 37.5 & 8 & 100.0 & \\
\hline Not good & 24 & 96.0 & 1 & 4.0 & 25 & 100.0 & \\
\hline Total & 29 & 87,9 & 4 & 12.1 & 33 & 100.0 & 0.036 \\
\hline
\end{tabular}

Source: Data Processing Results, July 2018 


\section{DISCUSSION}

Based on the results of the study, the majority of women of childbearing age experienced poor vulva hygiene resulting in positive VVC. As candida albicans can grow in the vaginal area under conditions that are less clean and humid, women who are less knowledgeable about the importance of maintaining the cleanliness of the reproductive organs might adopt this behavior.

This is one of the predisposing factors that cause the emergence of VVC because poor hygiene of the reproductive organs can cause environmental changes in the vagina so that the normal flora will grow into pathogens ${ }^{12}$.

This research is in line with Kinsman OS, and Collard AE research where the risk of VVC was decreased by $60-70 \%$ in postmenopausal compared with younger women, and consistent with the fact that candidal vaginitis is found predominantly in women of childbearing age. The endocrine milieu of the host is an important risk factor for colonization and infection by Candida. ${ }^{13,14}$ This research is oriented to fertile women to identify the incidence of candidiasis which is seen from their personal hygiene through laboratory tests. As limited sample used in a short time there is a need for future research by using different samples and methods to produce a more accurate analysis.

Frequency distribution showed that women with VVC is $87.9 \%$ and negative VVC is $12.1 \%$. Among those with positive VVC, the vulva hygiene was good $(62.5 \%)$ while women with negative VVC had poor hygienic vulva (less than 4.0\%). According to Anindita's et al. ${ }^{15}$, patients with positive VVC had good hygienic vulva because the patients used hormonal contraception. The use of hormonal contraceptives increases the risk of the occurrence of vulvovaginal candidiasis by 2,39 times compared to the use of mechanical contraception. Hormonal contraception causes changes in reproductive distribution that facilitate the onset of reproductive tract infections ${ }^{6}$. Whereas in IUD contraception there is a possibility that the entry of microorganisms that cause infection including fungi and infection can occur through sexual intercourse ${ }^{6}$. According to Jessica et al. ${ }^{6}$, hormonal effects of contraceptive pill can cause changes in the structure of the vaginal epithelium and cervix as well as irregular patches and bleeding, so that some types of germs can spread upwards and cause infection.

Factors affecting pregnancy iclude vulvovaginal candidiasis, diabetes mellitus, use of antibiotics, hormonal contraceptives, corticosteroid treatment ${ }^{15}$. Negative VVC with poor hygienic vulva is frequently influenced by the change of underwear. Changing underwear, less than 2 times a day increases the risk of the incidence of vaginal candidiasis 3.532 times greater than changing multiple times per day. The hot tropical climate of Indonesia will cause a lot of sweating, lading to damp vaginal condition. Humid vaginal conditions can stimulate Candida growth or facilitate fungi growth. Excessive fungus will cause the smelling and itching vagina ${ }^{15}$.

The use of broad-spectrum antibiotic is one of the predisposing factors that influence the occurrence of candida infections, such as butoconazole, clotrimazole, miconazole, econazole, fenticonazole, sertaconazole, ticonazole, terconazole. These are also diverse effective topical azole agents wich are accessible in a variety of formulations for VVC treatment, because they are notably safe and well tolerated. However, oral azoles can cause systemic toxicity dramatically with ketoconazole. Therefore, the biologically active components of herbal plants improve human health through the herbal derived medicine as an alternative source. Cumulative evidence suggests that some Chinese herbal medicines, including Syngonanthusnitens, Euphorbia hirta L, Centellaasiatica, Cymbopogoncitratus (DC) Stapf (Gramineae), Areca Cathechu, L. Piper Betle L., Terminaliacatappa have a beneficial role in slowing progressive VVC disease ${ }^{3}$.

This is in line with Sadri's research ${ }^{16}$, in Indonesia that there are around $70 \%$ of women experiencing vaginal discharge problems. Leucorrhoea that occurs in women is mostly due to the lack of awareness to maintain health, especially in the cleanliness of genital organs. The incidence of vaginal discharge is mostly caused by the bacteria of vulvovaginal candidiasis this is also due to many women who do not know how to clean the vaginal area ${ }^{16}$.

Based on the results of the study poor vulva hygiene was higher among positive (96.0\%) than negative VVC (4.0\%). Similarly, more women with VVC positive $(62.5 \%)$ had good 
vulva higine than those with VVC negative $(37.5 \%)$. The results of statistical analysis also showed $\mathrm{p}=0.036(\mathrm{p}<0.005)$, which means that there was a significant relationship between vulva hygiene and the incidence of vulovaginal candidiasis.

Similar with Anindita's study ${ }^{15}$, the majority of respondents in the case group (60\%) wiped vagina from back (rectum) to front. Whereas in the control group, most of the respondents $(62.2 \%)$ have done it correctly Chi-square test obtained $\mathrm{p}$ value $=0.033(\mathrm{p}<0,05)$ and the OR value is $2.471(95 \% \mathrm{CI}=1.061-5755)$. This means that the relationship between vaginal douches and vulvovaginal candidiasis incidence was statistically significant. The risk of developing vulvovaginal candidiasis among those who wint the vagina incorrectly is 2.471 times greater than those who rinsed did properly ${ }^{17}$.

The results of other studies found that there were 29 cases of VVC $(0.70 \%)$ of $47 \mathrm{VVC}$ cases in the STI Division with a total of 4,099 patients visiting the trermatoveneorology clinik. More prevalence of VVC cases found at the age of 15-24 years and 25-44 years can be caused by increasing of sexual activity, poor female hygiene, contraceptive use and antibiotic abuse that can spur overgrowth of Candida fungi ${ }^{12}$.

\section{CONCLUSION}

Based on the results of the research, it can be concluded that there is a relationship between vulva hygiene and vulvovaginalis candidiasis in women of childbearing age at Cipayung PHC in 2018.

\section{RECOMMENDATION}

Women of childbearing age are advised to maintain vaginal hygiene, which can be done by wiping the genital area with water and soap regularly after urination or performing bowel movements wiping from front to back or rectal area. It is recommended to wash hands before and after urination, change pads at least 3 times a day to avoid infection and change underwear at least 2 times a day or if it is moist.

\section{ACKNOWLEDGEMENT}

The author would like to express deepest gratitude to all doctors, nurses, midwives and staff of The Cipayung PHC, so that this research could be carried out successfully.

\section{REFERENCES}

1. Reza Faraji. Prevalence of vaginal candidiasis infection in diabetic women. African J Microbiol Res. 2012;6(11):2773-8.

2. Karo MB, Tambaip $T$, Hatta $M$, Simanjuntak T, Irmawaty L, Rina T, et al. A mini review of Indonesian medicinal plants for Vulvovaginal candidiasis. Rasayan J Chem. 2017;10(4).

3. Karo MB, Kamelia E, Miko H, Simanjuntak TP, Hatta M. Effects of Herbal Plants on Candidiasis Vulvovaginalis Therapy. Am J Lab Med. 2016;1(3):65-8.

4. Paramita DA, Nadeak K, Hutapea R. Gambaran spesies candida penyebab kandidiasis vulvovaginalis rekuren di RSUP Haji Adam Malik Medan. Maj Kedokt Nusant J Med Sch. 2017;47(2):5860 .

5. Nelson M, Wanjiru W, Margaret MW. Prevalence of Vaginal Candidiasis and Determination of the Occurrence of Candida Species in Pregnant Women Attending the Antenatal Clinic of Thika District Hospital, Kenya. Open J Med Microbiol. 2013;03(04):264-72.

6. Jessica P, Widyawati, Armalina D. Hubungan antara Terjadinya Kandidiasis Vulvovaginalis dengan Penggunaan Kontrasepsi Hormonal. J Kedokt Diponegoro. 2016;5(4):1493-9.

7. Nugraheni D, Agusni I, Ervianti E. Profil enzim secreted aspartyl proteinase (SAP) pada isolat pasien kandidiasis vulvovaginalis (KVV) di RSUD Dr. Soetomo Surabaya. PLoS Negl Trop Dis. 2015;9(4):1-8.

8. Arfiputri DS, Hidayati AN, Handayani S, Ervianti E. Risk factors of vulvovaginal 
candidiasis in dermato-venereology outpatients clinic of soetomo general hospital, Surabaya, Indonesia. African J Infect Dis. 2018;12(Special Issue 1):90-4.

9. Apriani K, Suriadi, Febrianti tri rina. Korelasi Antara Perilaku Vulva Hygiene dengan Kejadian Keputihan pada Mahasiswa Program Studi Keperawatan Fakultas Kedokteran Universitas Tanjung Pura Pontianak. 2014;1-7.

10. Harnindya D, Agusni I. Retrospective Study: Diagnosis and Management of Vulvovaginalis Candidiasis. Berk Ilmu Kesehat Kulit dan Kelamin. 2016;28(1):42-8.

11. Nuraini S, Herliani Y, Mulyani N, Tajmiati A. Mini Review: Prevalensi Vulvovaginosis di Indonesia. J Kesehat Tasikmalaya. 2018;1(3):7-12.

12. Tasik NL, Kapantow GM, Kandou RT. Profil Kandidiasis Vulvovaginalis Di Poliklinik Kulit Dan Kelamin Rsup Prof. Dr. R. D. Kandou Manado Periode Januari - Desember 2013. e-CliniC. 2016;4(1).
13. Kinsman OS, Collard AE. Hormonal factors in vaginal candidiasis in rats. Infect Immun. 1986;53(3):498-504.

14. Spinillo A, Bernuzzi AM, Cevini C, Gulminetti R, Luzi S, De Santolo A. The relationship of bacterial vaginosis, candida and trichomonas infection to symptomatic vaginitis in postmenopausal women attending a vaginitis clinic. Maturitas. 1997;27(3):253-60.

15. Martini S, Anindita W. Vaginal Candidiasis Occurrence Risk Factors in KB Acceptors. Indones J Public Heal. 2006;3(1):24-8.

16. Sadri. Hubungan Personal Hygiene dan Peran Orang Tua terhadap Kejadian Keputihan (Flour Albus) pada Remaja Putri di SMA Negeri I Calang Kabupaten Aceh Jaya. 2014.

17. Armerinayanti N, Lestari D. Risiko Kandidiasis Serviks Pada Wanita Usia Subur Akseptor Kontrasepsi Hormonal. WMJ (Warmadewa Med Journal). 2018;3(1):22. 